\title{
Research on Party Innovation Construction in Universities Based On the Scientific Development
}

\author{
Junwei Shi \\ Hebei Agricultural University, \\ Baoding,China
}

\begin{abstract}
The scientific development is an important guiding principle for China's economic and social development, it is the major strategic thinking of socialism development with Chinese characteristics must adhere and implement, is also an important guiding ideology grassroots party building of colleges and universities. This paper based on a deep understanding and accurate grasp of the scientific development connotation, the spirit and the basic requirements, elaborated under the command of scientific development, the necessity of the grass-roots party innovation construction work in the universities, it is concluded that promoting innovation is conducive to the development of grass-roots party.
\end{abstract}

Keywords: Basic party construction; Scientific development; Innovation; University;

\section{INTRODUCTION}

Scientific development is the guiding ideology of the Communist Party in China, it is a part of the theoretical system of socialism with Chinese characteristics, to advance the cause of continuous reform and development has important strategic significance. Grassroots party building work is an important basis for all the party's work and its effectiveness,strengthening and improving party building under the new situation,we must strictly in accordance with the requirements of the Seventeenth Party Congress,focused on building reflect the scientific development, and in line with the local characteristics of grass appraisal system of party building work, so that grassroots party building and further onto the scientific, standardized and institutionalized development track.

Strengthening grassroots party organizations is of great significance, it has a very important significance for promoting the building of a harmonious socialist society, consolidating the party's ruling status and governance foundation, protecting the image of the party at the grassroots masses, promoting and enhancing of basic living standards of the masses. However, with the rapid development of China's economy and society, grass-roots party building work is facing many new problems and situations, how to identify and solve them as an important task for us.

\section{Grassroots Party Building Theory Analysis}

\subsection{Definition of Grassroots Party Building}

Grassroots party building is mainly party development, in general party building, major events within the party and the daily work, as well as the spread of the Party's policy and advocacy activities.

\subsection{Theory of Party Building}

Party building has a decisive significance for the Chinese revolution. Only by strengthening the party building, we can achieve the party's leadership of the Chinese revolution, and win the victory of the Chinese revolution finally. The main content of the party building includes ideological, organizational, style of work construction. As far as the Communist Party of China construction, it is including that: Firstly, adhere 
to the fundamental purpose of serving the people, maintain and carry forward the Party's fine style of work; secondly, stick to maintain the party's unity and solidarity, and strictly implement democratic centralism; thirdly, accept supervision from the party and non-party to perform the party's supervision function; Fourth, efforts to train and bring up new successors to the cause of proletarian revolution and development of new party members, disciplined and organized the party member troop. The great significance of party construction theory is mainly manifested in the following aspects: to keep the party's advanced nature, maintain the party's leadership role as the core, led the Chinese people to the great victory of the Chinese revolution; Enrich and develop marxist party's important theory of the proletariat thought; In reform, opening up and socialist market economy condition, has an important significance to strengthen the construction of the party. Ideology construction should be put in the first out of the party's construction, and the organization construction is the material basis for the party's construction, the style of work construction embodies the party's image timely, these are closely linked and inseparable,therefore,we must put the party's thought construction, organization construction and style construction together, to promote the continuous development of the party's construction.

The construction of the party is the party led the Chinese people of all ethnic groups work together, mutual solidarity, overcome various difficulties, take the bull by the horns, constantly from victory to victory of a powerful weapon. As early as in 1939, Mao Zedong in the "<communists> foreword", put the party building as one of three magic weapons in the Chinese Revolution, shows the important status and role of party building, reflects the importance of the party's construction plenarily. At the moment, the party building work under the new situation facing the test of ability to govern, the test of social transformation, market economy test, the test of the international environment, and gradually accept more complex and more severe test. Therefore, we must continue to reform and innovation, to strengthen and improve party building in the spirit of reform, improve the party's construction goal, developing the contents of the construction of the party, only in this way can better realize the socialist harmonious society and the comprehensive construction affluent society's goal, to resolutely implement the scientific development.

\section{Scientific Development Theory Overview}

The scientific development fully inherited and developed the theoretical achievements of Marxism-Leninism,Mao Zedong Thought and Deng Xiaoping Theory, and fully recognize and proposed after take into account the economic and social development in various stages of experiences and lessons, and that is of epoch-making significance, has great development prospects, which is major theoretical idea for building a harmonious socialist society, the construction prosperous, strong, great China must insist for a long time.Its scientific meaning is: "the first prerequisite is to develop the; the core is people-oriented; the holistic approach is overall consideration; the basic requirement is a comprehensive, coordinated and sustainable."

Scientific development is the collective wisdom of our party, summarize the essence of times spirit with a very rich scientific connotation and high theoretical level, it is the great wealth of the Party and the country. Only firmly establish and earnestly carry out and implement the scientific development, to promote the continuous development of socialist material civilization and spiritual civilization; to ensure a comprehensive, healthy and sustainable development of China's socialist harmonious society; to achieve a comprehensive well-off society, and ultimately achieve the goal of common prosperity; to promote the great cause of socialism with Chinese characteristics forward effective; to make our Party's ruling foundation and ruling position more unbreakable. 
Scientific development, is not only conducive to people's living standards and quality of life continue to improve, but also to the continuous improvement of the comprehensive national strength and speed of development ,it is the benefits the country's strategic guidelines. Therefore, we must seriously practice and learn the scientific development. In fact, the scientific development, which is to guide the direction of socialist construction, illuminate the socialist path of development, clear socialist development goals and optimize important guiding ideology of socialist construction program, it is a concrete manifestation of China's continuous development. Scientific development is people-oriented, comprehensive, coordinated and sustainable development concept. "People-oriented", is to take the interests of the masses in the first place, the interests of the people all the work party and country as the starting point and goal, we continue to meet all the needs of the people, promote the comprehensive development of man; "comprehensive", is to the improvement of the socialist market economic system, to maintain rapid, healthy and sustainable development, accelerate the construction of political civilization and spiritual civilization construction, formate material civilization, political civilization and spiritual civilization, and make these three coordinated and complemented, in order to achieve the comprehensive development of socialism; "coordination" is to coordinate all development, balancing the interests of all parties, to promote domestic and foreign, economic and social,coordinated development of urban and rural, eventually reach all parts of the country, in the field of each area, each enterprise, various kinds of coordinated development; "Sustainable" is to guarantee the harmony of man and nature, man and society development, and deal with the economic development and population growth with the relation between resource utilization and ecological environment protection, promote the whole country and society to achieve production development, affluent life, ecological good healthy.

\section{The Inevitable Requirement of Grassroots Party Construction by Scientific Development in Colleges and Universities}

\subsection{Adhere to Promote the Development}

The first prerequisite is development of the scientific development. Universities grassroots party organizations to implement the Party's basic line and education policy, played an important role in the reform and career development of universities, a strong impetus to the reform, development and stability of the school. Promote innovation and grassroots party building, it is necessary to clarify its important responsibility, promote the development of effective measure and working with center to examine the effects of the grass-roots party organization construction. First, we must adhere to the primary task of development. Grass-roots party organizations in the work of thinking, it is necessary to firmly establish the idea about "around the center stresses the party construction, pays special attention to the party to promote the center", rather than just Take the matter on its merits.Second, we must implement the party tube talented person principle. People is the main part of the school development, but also a decisive factor for school development. The basic-level party organization must set up human resources is the important concept of school development, make the talents work in the school construction and development in an important strategic position, play in promoting reform and development of ideas, organization and personnel guarantee function. Third, we must strive to create an environment to encourage and protect innovation and atmosphere. In insist on improving the quality of higher education, content development conditions, to fully mobilize and play the enthusiasm, initiative and creativity of staff and students, make advocate innovation, the pursuit of innovation and excellence, especially leading cadres of a kind of value orientation 
and conscious action.

\subsection{Adhere to the People-oriented}

The core of the scientific development is people-oriented. Basic-level party organization's body is a party member, the service object is the people, which requires the basic-level party organization must always adhere to the people-oriented, full play the main role of party members, and develop the most the fundamental interests of the masses. First, to establish a "practical projects" mechanism. Each year on the basis of investigation and study, under the big strength to solve most concerned about the staff and students, the most direct, the most realistic problems, work diligently, sincerely for the interests for the masses; Second, we should strengthen inner-party democracy system construction, expand intra-party democracy mechanism. To respect the principal position of party members, actively adopts the system of party affairs, inner-party information sharing, to improve the party members' sense of responsibility and mission; Third, we should establish incentive mechanism. Adhere to the selection activities on a regular basis, vigorously commendation advanced grassroots party organizations, outstanding party members and party cadres.

\subsection{Adhere to A Comprehensive, Coordinated and Sustainable Development}

The basic requirements of scientific development is comprehensive, coordinated and sustainable development. Adhere to a comprehensive, coordinated and sustainable development, we must pay attention to grasp two aspects of construction. First, the culture construction. Strengthening cultural construction must adhere to the socialist core value system of ideological guide, strengthening the teachers and students staff to the leadership of the communist party of China, the socialist system, reform and opening up, the comprehensive construction well-off society goal belief and confidence; Play to the ideological and political education function, strengthen the rule of law concept of education, enhance the legal awareness of staff and students and good faith consciousness, guide the people rational legally to express their interests and desires, and properly handle all kinds of disputes and conflicts of interest; the second is the system construction. Strive to do the party's leadership, teaching and scientific research, administration and the party's own construction system of the organic link, ensure scientific decision-making, democratic decision-making, and after work. Many colleges and universities is not short of system, they lack of mechanism to ensure the system implementation. Therefore, to strengthen the party organizations, party members and the communication between teachers and students, establishing and perfecting scientific and effective interest coordination mechanism, expressing mechanism, conflict mediation mechanism, to correctly handle the contradictions among the people of the new situation.

\subsection{Adhere to theFundamental Method of Overall Consideration}

Overall consideration as its fundamental approach of the scientific concept of development, the university internal exist in the teaching of scientific research, management and logistics staff three teams, the interests of the two groups of students and retired workers. Because they are in different status and positions, have their own perspective on the same thing and interests. Therefore, how to coordinate, good three teams, the relationship between the two groups, concerning the overall situation of reform and colleges development. To overall consideration all aspects of the interest relationship, school party leaders must always goes down to the basic unit, timely understanding of basic situation, emotional communication, information communication and staff, let the staff fully understand the situation, and listen to their opinions and suggestions. 


\section{CONCLUSIONS}

Actively carry out the learning party organization to create activity, research and explore the ideas and patterns of learning party organization and construction. School leadership team to around the center work of the college, led the broad masses of teachers with college practice, give full play to "to promote the development and service of the masses, the cohesion of the people, promote harmony" spirit, closely around the "how to enhance the core competitiveness of College" in-depth development of strategic thinking and the theory of academic learning and key work, in-depth primary research, analyzes the difference and in-depth discussion, formulate rectification measures, strengthen the group learning mode.

Practice has proved that the grass-roots party organizations to the work of Party building and teachers, personnel training, teaching, scientific research, platform construction and foreign exchange with the organic integration, the grass-roots party organizations to promote the development of teaching, scientific research, teachers and students' ideological education, talent growth, make the party building work depth, content, innovation, characteristics, aims to enhance the scientific level of Party organization, really make the grass-roots party organizations to become college political core and fortress.

\section{References}

[1] Dong Limin, Jiang Daming, led by scientific development view, strengthen grass-roots party construction in colleges and universities work [J]. China power education, 2010 (19) : 136-137.

[2] Wang xiaoman of the Scientific Concept of Development and Innovation of University grassroots party building $[\mathrm{J}]$.Beijing Education, 2009 (13): 19-21.

[3] Xiao zhiyi. Research on the Level Evaluation System Construction of Grass - roots Party Construction Work -based on the Scientific Outlook on Development [D]. XiangTan University, 2012.

[4] Capital Normal University party construction team. The concept of scientific development with the grass-roots party construction innovation $[\mathrm{J}]$, Journal of Capital Normal University (Social Science Edition), 2008 (2) : 135-140. 